\title{
PERSPEKTYWY I WYZWANIA BADAŃ NA STYKU ARCHEOLOGII I SZTUKI
}

\author{
PERSPECTIVES AND CHALLENGES \\ ON THE EDGE OF ARCHAEOLOGY AND ART
}

\author{
Monika Stobiecka \\ orcid.org/0000-0003-3774-6159 \\ Wydział Artes Liberales, Uniwersytet Warszawski \\ ul. Dobra 72, 00-312 Warszawa, Polska \\ m.stobiecka@uw.edu.pl
}

\begin{abstract}
The main goal of this paper is to reflect on the perspectives and challenges of art and archaeology research. The paper investigates main objectives through the lens of the art historian and archaeologist. Even though, the study on relations between art and archaeology has a long tradition in archaeology and the most famous researchers reflected on those tensions (Colin Renfrew, Michael Shanks, Andrew Jones, Ian Russell, Paul Reilly, Paul Bonaventura), art and archaeology approach is still not a coherent and systematic methodological framework. To deal with this notable lack, the author revises previous studies and points at the possible advantages of the development of studies at the border of art, archaeology and aesthetics. The main problems are illustrated and discussed in reference to archaeological museums and the Polish contemporary art represented by Hubert Czerepok, Agata Ingarden, Agnieszka Kalinowska, Agnieszka Kurant, Robert Kuśmirowski and Joanna Rajkowska.
\end{abstract}

KEY WORDS: archaeology, contemporary art, Polish contemporary art, aesthetics in archaeology, theory of archaeology, archaeological imagination

Relacje między sztuką współczesną a archeologią od dawna znajdują się w orbicie zainteresowań badaczy przeszłości. Mimo że przepływem między dziełami a toposami archeologicznymi zajmują się takie autorytety, jak Colin Renfrew, Michael Shanks, Andrew Jones, Ian Russell, Paul Reilly czy Paul Bonaventura, nadal nie ma obowiązującej, jasnej, systematycznej i koherentnej wizji, jak prowadzić badania na styku sztuki i archeologii (art and archaeology based research).

Przyjmując perspektywę historyczki sztuki i archeolożki, w tekście zastanowię się nad wyzwaniami stojącymi przed podejściem do badań na styku sztuki i archeologii. 
Mierząc się z dorobkiem dotychczasowych studiów, spróbuję wskazać na potencjalne korzyści z zacieśnienia współpracy międzydyscyplinarnej, a także zasugeruję remedia na zaobserwowane problemy natury metodologicznej i pojęciowej. Koncentrując się na perspektywach i wyzwaniach wyrastających przed badaniami na styku archeologii i sztuki, zaproponuję, aby gruntem nowych poszukiwań teoretycznych i praktycznych ustanowić muzea archeologiczne, jako miejsca usytuowane w obszarze spotkań archeologii, sztuki i estetyki. Powołując się na zagraniczne wystawy oraz na prace artystów polskich, będę się starała wskazać na potencjalne scenariusze współpracy między archeologią i sztuką współczesną. Sondując relację archeologii i sztuki, będę negocjować i mapować możliwości zacieśnienia więzi między archeologią, sztuką i estetyką, a także wskazać korzyści naukowe i wystawiennicze wynikające ze zrewidowanego podejścia do relacji archeologiczno-artystycznych. Terminy ,archeologia”, „sztuka” i „estetyka” będę rozumieć w następujący sposób: 1) archeologia - nauka o rzeczach z przeszłości zmierzająca do rekonstrukcji przeszłego życia ludzi i nieludzi (Olsen, Shanks, Webmoor, Witmore, 2012; Renfrew, Bahn, 2002), ale także archeologia jako zestaw metafor, poetyka praktyki wykorzystywana przez przedstawicieli innych dyscyplin naukowych (González-Ruibal, 2013); 2) sztuka - w ujęciu instytucjonalnym, czyli wszystko to, co jest nazywane sztuką przez aparat instytucjonalny (krytyków, historyków i badaczy sztuki, galerie, muzea i rynek sztuki) (Belting, 2003); 3) estetyka - w ujęciu heterogenicznym jako perspektywy wykraczające poza kantowską estetykę piękna i wzniosłości, aktualizujące ten repertuar o m.in. estetykę brzydoty i abiektu (Kristeva, 2007), estetykę fragmentu i ruiny (Edensor, 2005; Simmel, 2006; Olsen, Pétursdóttir, 2014), estetykę codzienności (Saito, 2007), estetykę antropocenu (Davis, Turpin, 2015), estetykę nowego materializmu (Parikka, 2015), nową estetykę (Welsch, 1997). Oddzielnego komentarza wymaga użycie pojęcia materialności. Będę je tu rozumieć przede wszystkim w odniesieniu do archeologii jako wpisane w praktykę badaczy przeszłości (Olsen, 2013; Olsen i in., 2012). Zatem aby lepiej zoperacjonalizować użycie tego terminu w tekście, zawężę jego znaczenie, nie w pełni włączając się w debaty prowadzone przez historyków sztuki (Wróblewska, 2014; Poprzęcka, 2019).

\section{STAN BADAŃ W OBSZARZE ARCHEOLOGIA - SZTUKA - ESTETYKA}

Badania punktów stycznych między archeologią, sztuką i estetyką obejmują zagadnienia związane $\mathrm{z}$ estetyką $\mathrm{w}$ archeologii, najczęściej ujmowaną jako refleksje nad estetycznym wymiarem artefaktów w przeszłości (Vickers, 1994; Gosden, 2001; Currie, 2012) oraz możliwościami interpretacyjnymi wyrastającymi z relacji między sztuką współczesną a archeologią (Pearson, Shanks, 2001; Renfrew, 2003; Jameson, Ehrenhard, Finn, 2003; Pollard, 2004; Renfrew, Gosden, DeMarais, 2004; Harrison, Schofield, 2010; Bonaventura, Jones, 2011; Vilches, 2011; Russell, 2011; Danielsson, Fahlander, Sjöstrand, 2012; Shanks, 2012; Russell, Cochrane, 2014; Deshoulières, 
2014; Chittock, Valdez-Tullett, 2016). Przedstawiciele drugiego z wymienionych horyzontów badawczych, którzy koncentrują się na kwestiach teoretycznych, mimo odmiennych przedmiotów zainteresowań ${ }^{1}$, wskazują na podobne kwestie związane z negocjowaniem obszaru między sztuką a archeologią.

Andrew Jones i Paul Bonaventura we wstępie do tomu pokonferencyjnego Shaping the past: sculpture and archaeology zwracają uwagę, że zarówno historia sztuki, jak i archeologia są ,zainteresowane synoptyczną widzialnością przeszłości i tym, jak może ona funkcjonować obecnie" (Jones, Bonaventura, 2011, s. 6). Moim zdaniem ta komparatystyczna wskazówka pozwala zadać pytania o to, jak materializuje się przeszłość w obiektach archeologicznych, czy jej obraz koreluje z reprezentacjami artystycznymi, jaką wizję minionych dziejów oferują nam obecnie artefakty i dzieła sztuki.

Flora Vilches z kolei w interesującej w kontekście praktyki wykopaliskowej interpretacji pracy Roberta Smithsona Incidents of Mirror-Travel in the Yucatan zwraca uwagę na arcyistotną kwestię. Twiedzi, że sztuka antycypuje wiele problemów teorii archeologii (Vilches, 2011). Vilches, prowadząc rozważania, sygnalizuje, że to amerykański artysta Smithson, przedstawiciel land artu, pierwszy naświetlił problem między subiektywną a obiektywną reprezentacją przeszłości konstruowaną przez archeologów. Myślę, że ten ważny trop ma duże znaczenie przede wszystkim w kontekście reprezentacji i wizualizacji wiedzy, kierując uwagę na kreatywny potencjał artystów w konstruowaniu, a nawet kontestowaniu reprezentacji archeologicznych. Zarówno jego uwagi, jak i innych artystów mogą w takim ujęciu stać się ożywczym impulsem do formułowania nowych problemów w archeologii.

Colin Renfrew powołuje się z kolei na innego artystę land artu Richarda Longa, wskazując, że artystyczna wyobraźnia sytuuje się blisko wyobraźni archeologicznej (Renfrew, 2014; por. Shanks, 2012). Podobnie jak Michael Shanks, odpowiedzialny za konceptualizację pojęcia „wyobraźnia archeologiczna” (archaeological imagination), Renfrew wierzy w potencjał archeologicznego imaginarium, repertuar społecznych wyobrażeń o archeologii i jej historyczno-romantycznych korzeni, które mogą być twórcze dla artystów, zaś archeologom pozwalają otwierać nowe perspektywy interpretacyjne. Podobny wątek podejmuje Ylva Sjöstrand, która jest przekonana, że czytanie sztuką obiektów archeologicznych może przewartościować praktykę badających „rzeczy z przeszłości” (Sjöstrand, 2017). Jej uwagi sytuują się blisko spostrzeżeń Helen Chittock i Joany Valdez-Tullett, które sugerują, że zwrot ku rzeczom i zwrot materialny w humanistyce zbliżyły do siebie sztukę i archeologię (Chittock, Valdez-Tullett, 2016, s. VI). Zwracając uwagę na wspólną genealogię archeologii i historii sztuki, autorki optują za zacieśnieniem więzi między dyscyplinami. John Jameson wskazuje, że współpraca na polu archeologii i sztuki pozwoliłaby archeologii wyjść poza dominujące europocentryczne ramy myślowe, a także skutecznie dotrzeć

${ }^{1} \mathrm{~W}$ tym miejscu chcę także zaznaczyć, że w ostatnich dekadach odbywały się interesujące badania nad stykiem archeologii i teatru (Pearson, Shanks, 2001), niemniej w tekście skupiam się przede wszystkim na sztukach wizualnych, nie performatywnych. 
do szerokiej publiczności, w mediowanie archeologii angażując artystów (Jameson, 2003, s. 59, 62).

Także w Polsce dyskusje na styku archeologii, estetyki i sztuki mają już długą tradycję. W Warszawie od wielu lat trwają badania nad recepcją antyku (Miziołek, 2005; Miziołek, 2007; Kowalski, 2008), najbliższe horyzontowi klasycznie rozumianej historii sztuki. Dużą nadzieją na otwarcie nowych perspektyw i rozwój tego pola badawczego w kraju napawają projekty realizowane w środowisku poznańskich i gdańskich archeologów. Po serii ośmiu udanych spotkań z cyklu Estetyka w archeologii, organizowanych w Gdańsku przez Komisję Metod i Teorii Badań Archeologicznych Komitetu Nauk Pra- i Protohistorycznych PAN, konferencji Estetyka jako obszar badań archeologii - 15 lat później (Aesthetics as a Field of Studies of Archaeology), odbywającej się w Gdańsku w 2016 roku, niezwykle obiecująco prezentują się aktualne działania w Poznaniu, zwłaszcza współpraca archeologów z Uniwersytetem Artystycznym. Postacią, która od początku 2000 roku animuje badania na tym polu, jest Ewa Bugaj (Bugaj, 2003, 2004, 2012). Badaczka prezentuje istotne uwagi dotyczące prowadzenia poszukiwań na styku archeologii i sztuki. Szczególnie warte podkreślenia wydaje mi się zachęcanie archeologów do wykraczania poza kantowską estetykę piękna i promowanie nowych, alternatywnych spojrzeń na estetykę $\mathrm{w}$ archeologii. $\mathrm{Na}$ zainteresowanie zasługują też nowe badania inspirowane archeologią niedawnej przeszłości, realizowane przede wszystkim przez Dawida Kobiałkę, który bada zjawisko sztuki okopowej w obozach jenieckich na terenie Polski (Kobiałka, 2017).

Mimo zauważalnego wzrostu zainteresowania stykiem sztuki i archeologii ${ }^{2}$, nadal obserwuje się powszechną niechęć lub niezrozumienie projektów tworzonych w tym obszarze. Cytowana już Ylva Sjöstrand, zauważając inspirujący potencjał i przedstawiając stan badań na pograniczu sztuki i archeologii, ubolewa nad tym, że większość publikacji z tego zakresu została zignorowana w szerszym obiegu naukowym (Sjöstrand, 2017, s. 375). Jej uwagi korelują ze stanem rzeczy zarówno w archeologii zagranicznej, jak i w polskiej. Problemy te są bagatelizowane, często ulegają trywializacji, uproszczeniom, co przyczynia się do ich marginalizacji w teorii archeologii. Format prowadzonych badań jest często redukowany do studiów nad recepcją antyku czy pradziejów. Bliski jest zatem klasycznej historii sztuki, projektowi ikonologii Erwina Panofskyego czy nawet nosi cechy historyczno-artystycznego znawstwa w duchu Giovanniego Morelliego. Z tego względu studiowanie swoistej „wpływologii” nie stanowi atrakcyjnej propozycji dla archeologów, którzy traktują metody ikonograficzne czy ikonologiczne jedynie jako element swojego warsztatu.

Jeszcze mniej zrozumienia znajdują projekty na styku archeologii i estetyki, w których badacze stawiają sobie najczęściej za cel refleksję nad estetycznym wartościowaniem w przeszłości. Sprowadza się to w dużej mierze do artykułowania odważnych,

\footnotetext{
${ }^{2}$ Szczególnie warto podkreślić w tym miejscu bujny rozwój badań w tym nurcie nad sztuką naskalną, które ze względu na dotychczasowy dorobek zasługują na oddzielne omówienie. Te specjalistyczne kwestie pozostają poza moim obszarem zainteresowań. Ten temat w polskiej literaturze wyczerpująco omówiła Danuta Minta-Tworzowska (Minta-Tworzowska, 2017).
} 
lecz mało wiarygodnych hipotez (zob. Currie, 2012), które nierzadko albo prowadzą do bezowocnych dyskusji, albo są ignorowane ze względu na daleki od naukowego charakter. Badacze prezentujący to stanowisko z reguły sięgają po kategorię sprawczości rozumianą zgodnie z antropologiczną koncepcją Alfreda Gella, autora Art and Agency (Gell, 2013), jednak, jak stwierdza Chris Gosden, archeologom nadal brakuje narzędzi do kompleksowej analizy problemu estetyki w archeologii (Gosden, 2001, s. 163).

Renfrew, Russell, Cochrane, Jones, Bonaventura, Vilches czy Sjöstrand wprawdzie sięgają po narzędzia historii sztuki, lecz z ich tekstów nie wyłania się w pełni koherentna wizja, która mogłaby odpowiedzieć na wycinkowość badań na styku archeologii, sztuki i estetyki. Jak prowadzić badania na styku archeologii i sztuki? Jakich narzędzi metodologicznych używać? Jak konceptualizować podejmowane problemy? Jak uniknąć oskarżenia o nienaukowość? Jak w rzeczywistości otwierać nowe perspektywy w archeologii, myśleć archeologią i działać sztuką? Sądzę, że nie ma obszaru bodaj lepiej odpowiadającego na zaproszenie do rozpatrzenia tych problemów jak muzea archeologiczne, które świadomie decydują się na wprowadzanie dzieł sztuki do narracji wystawienniczych. Moim zdaniem wymagają jednak wypracowania nieco innych ujęć teoretycznych niż istniejące oraz postawienia konkretnych pytań badawczych dotyczących relacji archeologii i sztuki, problemu reprezentacji, charakteru doświadczenia przeszłości, temporalności i materialności czy wreszcie statusu artefaktu jako eksponatu wobec dzieł sztuki. Gorącym wezwaniem do formułowania tego typu pytań stają się wystawy usytuowane na obciążonym historyczną schedą wspólnej genealogii styku archeologii i sztuki (Tilley, Shanks, 1992; Olsen i in., 2012).

\section{CZEGO CHCĄ ARTEFAKTY?}

Paradygmatem wystawienniczym dla muzeów archeologicznych stał się w XIX wieku estetyczny typ prezentacji artefaktów (Vergo, 2005). Ten model wystawiania obiektów archeologicznych powiązany był w swoich początkach z konstytuowaniem się archeologii jako samodzielnej dyscypliny akademickiej (Olsen i in., 2012; Hamilakis, 2013; Thomas, 2004). Archeologia poszukująca legitymizacji ilustrowała swoje tezy, porządkując artefakty wedle popularnej wówczas typologii. Obiekty uszeregowane $\mathrm{w}$ rzędach, ustawione $\mathrm{w}$ gablotach $\mathrm{w}$ ujęciu chronologicznym wizualizowały porządek czasu: narodziny, rozwój i upadek pradziejowych i antycznych kultur. W ramach tego typu prezentacji obiekty stały się markerami na osi czasu, zostały zredukowane do roli wizualnych znaków, a tym samym zdaniem Hamilakisa, Olsena, Shanksa, Webmoora i Witmore'a uległy estetyzacji. W istocie zgodzę się z wnioskiem wyprowadzonym przez ważnych teoretyków archeologii, chcąc jednocześnie podkreślić, że typologiczny porządek narzuca nam doszukiwanie się piękna. Po kantowsku rozumiane piękno odkrywamy w porządku (dispositio), regularności i logice typologicznej ekspozycji. Taki format wystawy ponadto nie odsyła zwiedzających do innych treści. Hermetyczny język podpisów, zrozumiały jedynie dla specjalistów, oddala obiekty od ich indywidualnych historii czy kontekstu archeologicznego. 
Estetyczny porządek wystaw, który na dekady zdominował muzea archeologiczne na całym świecie, narzucił zwiedzającym określony sposób percypowania obiektów archeologicznych. Jak pisał w 1989 roku Peter Vergo w przełomowym tomie obwieszczającym narodziny „Nowej Muzeologii” (Vergo, 1989), pogląd estetyczny zakładał rozumienie obiektów jako dzieł sztuki i doświadczanie ich na zasadzie duchowej kontemplacji. Krytykując ten paradygmat, Vergo pisał, że jest on ,arogancki i bezkompromisowy, oparty na założeniu, że widz posiada pewien poziom wykształcenia i wrażliwości" (Vergo, 2005, s. 323). Znaczenia społeczne, funkcjonalne czy archeologiczne artefaktów stały się dostępne tylko dla hermetycznej i ekskluzywnej grupy specjalistów, zaś na masowego odbiorcę zostało narzucone jarzmo postrzegania obiektów archeologicznych jako dzieł sztuki.

Ten paradygmat poskutkował tym, że większość zwiedzających muzea i stanowiska archeologiczne doszukuje się w nich estetycznych wartości (Ramos, Duganne, 2000, s. 25), zapominając o innych wymiarach obiektów z przeszłości. Mimo że archeolodzy już w latach 90. podnosili problem nadmiernej estetyzacji (w rozumieniu kantowskiej estetyki piękna) artefaktów, wydaje się, że model wystawienniczy ustanawiający artefakt dziełem sztuki nadal pozostaje jednym z wiodących w muzeach, zwłaszcza w wielkich galeriach narodowych, tzw. muzeach encyklopedycznych (Swain, 2009, s. 9). W 1992 roku Michael Shanks i Christopher Tilley porównali muzea archeologiczne do prezentacji ikon w Rosji, mówiąc, że ich kuratorem jest romantyczny homo artifex, dopatrujący się sztuki tam, gdzie nie zawsze można ją znaleźć (Tilley, Shanks, 1992, s. 72). Stwierdzili, że redukowanie znalezisk do roli obiektów artystycznych prowadzi de facto do ich fetyszyzacji (Tilley, Shanks, 1992, s. 73). Wydaje się, że ten wyjątkowy, ważny wniosek wyprowadzony przez Shanksa i Tilleya został przeoczony w rozważaniach nad muzeami archeologicznymi i w studiach na styku archeologii i sztuki.

W tym miejscu, parafrazując słynne pytanie W. J. T. Mitchella, warto byłoby zapytać, czy tego rzeczywiście chca artefakty? Czy artefakty w muzeach archeologicznych pragną być dziełami sztuki? Czy chcą się wyzwalać spod instytucjonalnie zakotwiczonego aparatu sztuki? Czy chcą uciec od estetycznego wartościowania? W kanonicznej już dla studiów nad kulturą wizualną publikacji Czego chca obrazy? Pragnienia przedstawień, życie i miłości obrazów Mitchell animuje dzieła sztuki i szuka odpowiedzi na postawione w tytule pytanie (Mitchell, 2013). Jak sam pisze o swoim celu:

[N]ie chodzi jednak o to, by uczynić z personifikacji dzieła sztuki kategorię nadrzędną, lecz by podać w wątpliwość naszą relację z dziełem i właśnie tę relacyjność obrazu i widza uznać za przedmiot badania. Chodzi o to, by uczynić przedstawienia mniej poznawalnymi, mniej oczywistymi, a także o to, by skierować ich analizę ku zagadnieniom procesu, afektu oraz podważyć pozycję widza: czego przedstawienie chce ode mnie lub od „nas” lub od „nich” lub od kogokolwiek innego? (Mitchell 2013)

Próbując zastosować kategorie Mitchella do badań artefaktów archeologicznych, należałoby podobnie sondować relacje widza $\mathrm{z}$ artefaktem, zastanowić się nad tym, 
czy faktycznie artefakty chcą ulegać redukcji wizualnej, czy chcą jedynie cieszyć oko zwiedzających muzea, czy raczej wykraczać poza tę optykę, opowiadać historię, wywoływać emocje i afekty? ${ }^{3}$

Myślę, że odpowiedzią mogłyby być właśnie projekty na styku archeologii i sztuki, nie tylko jako forma przepracowania długowiecznej relacji między dyscyplinami i ich wspólnej genealogii, lecz także jako próba wyjścia poza dominujące sposoby myślenia o obiektach archeologicznych. Interesująco w tym kontekście jawią się inicjatywy amerykańskiego archeologa Douga Bailey'a, który prowadzi badania w obszarze sztuka/archeologia (art/archaeology) (Bailey, 2017a, 2017b, 2018). Zamiast oddawać się teoretycznym rozważaniom, jak wielu spośród cytowanych wyżej badaczy, Bailey sam tworzy projekty na styku archeologii i sztuki. Wzorując się na wielkich nazwiskach sztuki współczesnej, jak Gordon Matta-Clark, Lucio Fontana czy Ai Weiwei, mapuje zupełnie nowe możliwości dla tej subdyscypliny. Podczas konferencji American Theoretical Archaeology Group w Syracuse University w 2019 roku Bailey, zainspirowany pracą Ai Weiweia Dropping a Han Dynasty Urn, dokonał zniszczenia amfory z San Francisco, a jej fragmenty rozdał uczestnikom performensu (ryc. 1). Założeniem, za znanym chińskim artystą, było „wyzwolenie” obiektu,

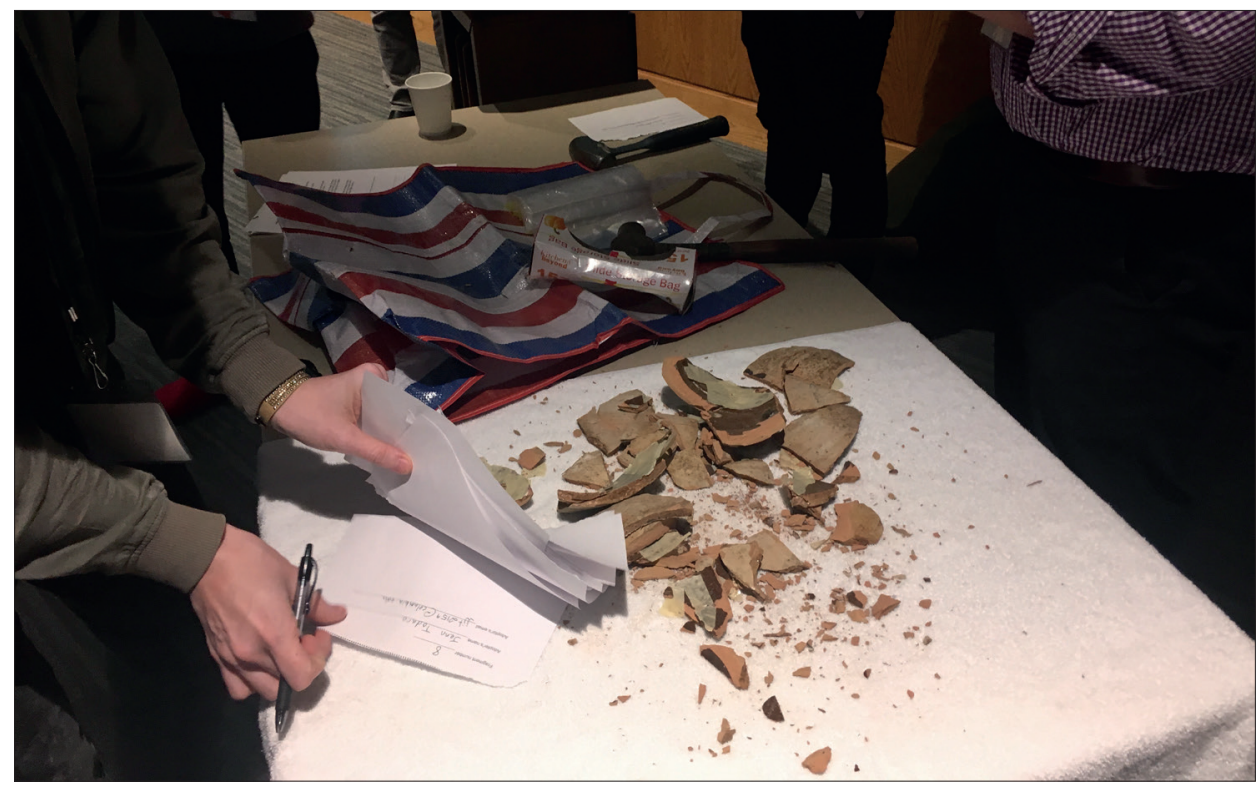

Ryc. 1. American Theoretical Archaeology Group w Syracuse University w 2019 roku, Doug Bailey, po zniszczeniu amfory z San Francisco (fot. Monika Stobiecka)

Fig. 1. American Theoretical Archeology Group at Syracuse University in 2019, Doug Bailey, after destroying the San Francisco amphora (photo by Monika Stobiecka)

${ }^{3}$ Tu warto byłoby się odnieść do dorobku studiów neuroestetycznych i neuromuzealnych, którymi w Polsce zajmuje się m.in. Dorota Folga-Januszewska, zob. Folga-Januszewska, 2015. 


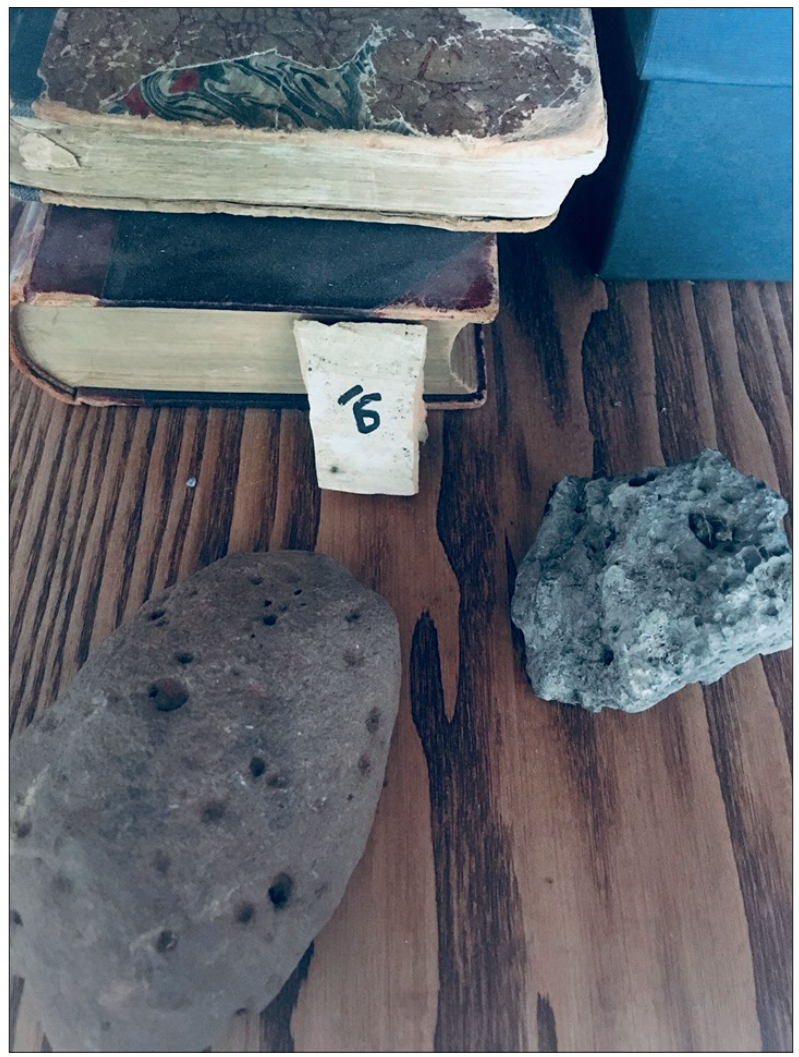

Ryc. 2. Fragment nr 16 podarowany autorce tekstu przez Douga Bailey'a po zniszczeniu amfory z San Francisco (fot. Monika Stobiecka)

Fig. 2. Fragment No. 16 given to the author by Doug Bailey after the destruction of the San Francisco amphora (photo by Monika Stobiecka)

uwolnienie go z przepełnionego muzealnego magazynu, a także swoista animacja. Każdy właściciel fragmentu amfory został poproszony o dokumentację jego życia po rozbiciu (ryc. 2). Podobnie potraktował swoje prace na stanowisku archeologicznym w rumuńskiej Magurze, gdzie sięgnął przede wszystkim do prac Gordona Matta-Clarka i Lucio Fontanty. Obserwując proces eksploracji stanowiska, skojarzył go z pogwałceniem powierzchni, nacięciami, które odnalazł przede wszystkim w twórczości Fontany (motywy otworów, buchi i nacięć, tagli). Swoje projekty w ramach sztuki/archeologii określa jako negocjowanie granic sztuki i archeologii, wykorzystywanie narzędzi, metodologii i tradycji obu, tworzenie prac i projektów poza wyjaśnieniem i interpretacją, które kwestionują i komplikują dotychczasowe praktyki.

Być może artefakty chcą być rozumiane właśnie w ten sposób, jako twórcze, plastyczne materie zapraszające do kreatywnych praktyk usytuowanych na dyscyplinar- 
nym styku. Chcą tym samym pobudzać wyobraźnię, zachęcać do budowania własnej wizji przeszłości, ożywać $\mathrm{w}$ interakcji z badaczami, artystami, a także zwiedzającymi w muzeach. Takie podejście kwestionuje paradygmat wizualny, w którym obiekty archeologiczne są zrównywane z dziełem sztuki (por. Currie, 2012), służą konfrontowaniu wartości estetycznych, a przy tym pozostają bierne, nie wywołują akcji, reakcji, emocji. Sugerowałabym zatem, aby albo zaktualizować repertuar estetyki w archeologii, sięgając po estetykę abiektu (Kristeva, 2007), estetykę dnia codziennego (Saito, 2007), estetykę fragmentu (Edensor, 2005; Simmel, 2006; Olsen, Pétursdóttir, 2014), estetykę antropocenu (Davies, Turpin, 2015), nową estetykę (Welsch, 1997) lub zwyczajnie zdecentralizować rolę poszukiwania estetycznych wartości w obiektach archeologicznych i zamiast tego dopatrywać się nowych możliwości czytania artefaktów, swoistej sprawczości artefaktów w zderzeniu z inspiracjami płynącymi ze sztuki.

\section{NOWE OBSZARY BADAWCZE}

Dotychczasowy dorobek w obszarze sztuki i archeologii często zdradza mielizny interpretacyjne, szczególnie widoczne dla historyków sztuki. Wynikają one po części z powtarzalności obieralnych przedmiotów badań. Mam tu na myśli przede wszystkim ciągłe wskazywanie na paralelę między nurtami land art i site-specific a archeologią. W literaturze przedmiotu dominują odwołania do Roberta Smithsona (Vilches, 2011; Pollard, 2004), Richarda Longa (Renfrew, 2003, 2014; Pollard, 2004), Marka Diona (Renfrew 1999, 2003; Vilches, 2007; Harrison, Schofield, 2010) i Anselma Kiefera (Harrison, Schofield, 2010; Harrison, 2011; Shanks, 2012).

Dzielone przez archeologów i Smithsona zainteresowania dotyczą kwestii materialności i entropii (Spalona drewniana szopa, 1970), reprezentacji miejsca (Nonsite, 1969; Mirror-travels, 1969) czy interwencji w krajobraz (Spiralna grobla, 1970). Często jednak interpretacje archeologów odnoszące się do twórczości Smithsona są pozbawione ważnych odniesień biograficznych, kontekstualnych, historycznych (por. Flam, 1996; Roberts, 2004) i funkcjonują raczej jako powierzchowne metafory niż rzeczywiste przedmioty analizy. To nieco przewrotne, że archeolodzy tak często odwołują się do Smithsona, którego opinia na temat archeologii i jej reprezentantów była nieszczególnie przychylna, a niektóre gesty artystyczne wprost wymierzone przeciwko badaczom przeszłości, np. w pracy Asphalt Rundown (1969), kiedy Smithson wylał asfalt w Cava de Selce niedaleko Rzymu w otwartym akcie zasłonięcia „,historycznej hałdy śmieci”, jak określał Rzym (Roberts, 2004, s. 105), czy w Incidents of Mirror-Travels to Yucatan (1969), gdzie kontestował i wystapił przeciwko imperialnym podbojom Johna Lloyda Stephensa, odkrywcy stanowisk majańskich.

Kolejnym eksploatowanym odniesieniem jest twórczość innego przedstawiciela land artu Richarda Longa. Colin Renfrew w pracach Longa, a szczególnie w słynnym cyklu Linii (Lines), widzi analogie do śladów badanych przez archeologów. Praktykę chodzenia artysty rozumie jako sposób okazywania szacunku dla neolitycznych 
monumentów (Renfrew, 2004, s. 14). Nie wyjaśnia jednak czytelnikowi, w jaki sposób dochodzi do tego wniosku. W innej publikacji prace Longa służą Renfrew do zestawienia $\mathrm{z}$ fotografiami eksplorowanych stanowisk archeologicznych. Odsłonięte mury ewokują kamienne ścieżki budowane przez artystę (Renfrew, 2003, s. 30). $\mathrm{O}$ ile na poziomie wizualnym ta analogia z pewnością przekonuje, o tyle Renfrew nie odpowiada na pytanie, w czym takie porównanie może pomóc archeologom? Jak penetrować znaczenia takich zestawień? Publikacje na temat sztuki odniesione do całego dorobku Renfrew, ważnego dla teorii archeologii, wywierają wrażenie raczej luźnych, a często nawet dość powierzchownych skojarzeń wizualnych nieszczególnie popartych refleksją teoretyczną. Gdyby potraktować je jak Atlas Mnemosyne Aby'ego Warburga (Warburg, 2016), zapewne mogłyby się stać interesującą pożywką do dalszych rozważań.

Colin Renfrew równie często powołuje się na prace Marka Diona, który w projektach Tate Thames Dig (1999) czy New England Dig (2001) przeprowadza wykopaliska, opierając się na podejściu sztuki i nauki (art and science). Tu Renfrew sięga po nawiązania do historii archeologii, szczególnie po znaczenie gabinetów osobliwości dla rozwoju muzealnictwa archeologicznego, co stanowi bardzo interesujący dialog z pracami brytyjskiego artysty. Zwraca także uwagę na rodzaj performatywnego podejścia do archeologii jako praktyki doskonale odtworzonej przez Diona w dwóch wspomnianych projektach.

Prace Anselma Kiefera stanowią z kolei ważne odniesienia do koncepcji Michaela Shanksa (2012, s. 23) czy metody badania sztuki archeologią proponowanej przez Radney'a Harrisona (por. Harrison, 2011) i Johna Schofielda (Harrison, Schofield, 2010). Archeolodzy podkreślają materialność prac niemieckiego artysty, odciągając uwagę od głównego wątku jego twórczości - mierzenia się z powojenną tożsamością Niemca jako oprawcy.

Sądzę, że powtarzalne odwołania wskazują przede wszystkim na pewien rodzaj metodologicznej niemocy. Sugeruję zatem w tym miejscu wypracowanie koherentnej ramy metodologicznej przy sięgnięciu po nowe dzieła sztuki. Uważam także, że zamiast powoływania się na często dość przypadkowe prace wyrwane z szerszego kontekstu twórczości danego artysty, warto byłoby zacząć od wspólnego dla archeologów, artystów i prac korzystających z motywów archeologicznych gruntu - muzeum archeologicznego.

Dzieła sztuki współczesnej są coraz częściej prezentowane w muzeach archeologicznych lub pod auspicjami projektów archeologicznych. W europejskich i amerykańskich muzeach te działania są wykorzystywane w animacji dziedzictwa archeologicznego (por. Jameson, 2003). W 2006 roku do narracji Muzeum Ołtarza Pokoju w Rzymie wprowadzona jest mozaika współczesnego włoskiego artysty Mimmo Paladino (ryc. 3). Słynny krytyk sztuki i kurator Achille Bonito Oliva identyfikuje mozaikę Paladino jako senne marzenie artysty, które stanowi kolizję dwóch współkształtujących je elementów: przeszłej kultury i kultury współczesnej fundującej wrażliwość artystyczną Paladino (Oliva, 2008). Achille Bonito Oliva wskazuje na to, że głównymi siłami działającymi w kompozycji są znak i materia, trawersujące 


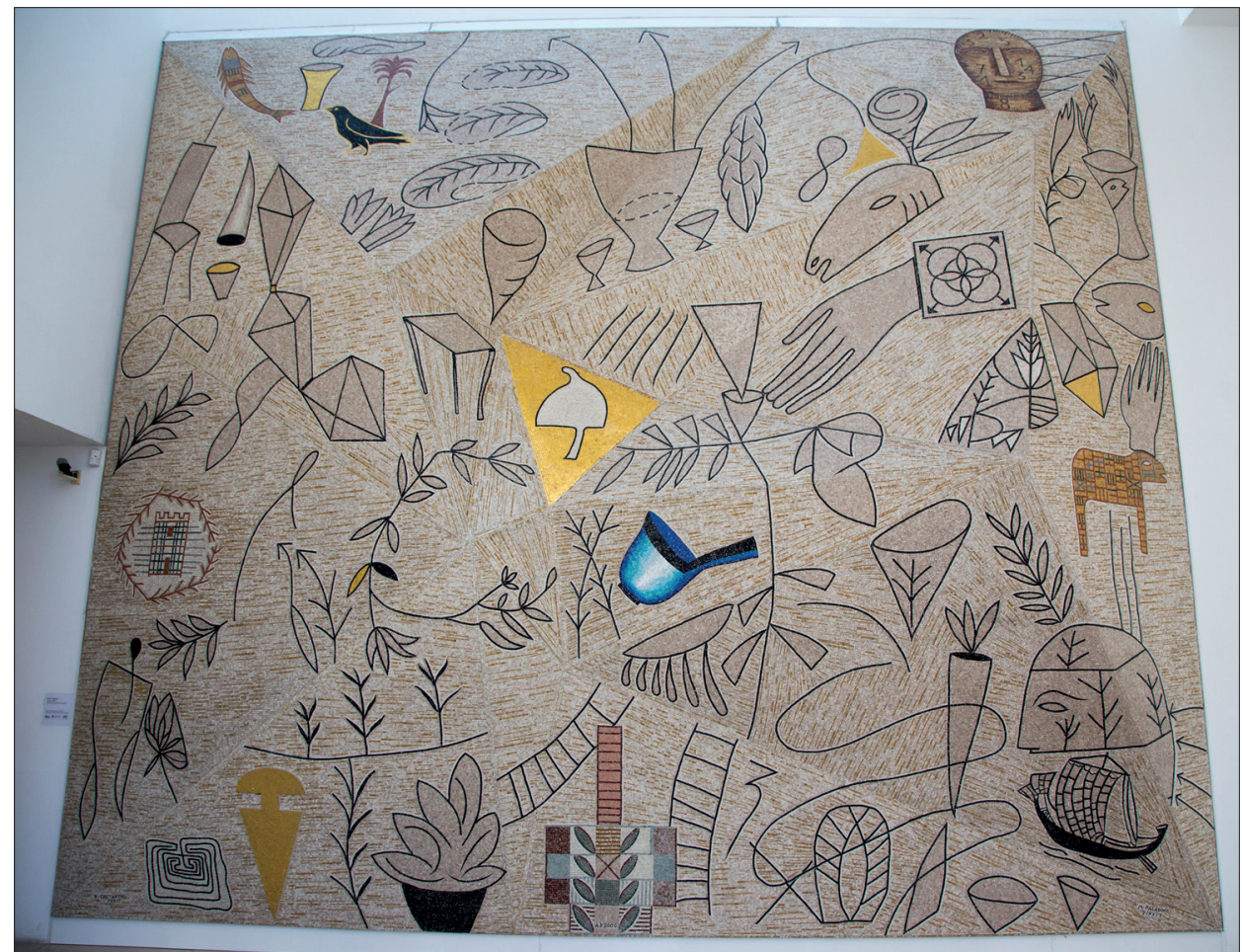

Ryc. 3. Muzeum Ołtarza Pokoju w Rzymie, mozaika Ara Pacis, aut. Mimmo Paladino, 2000 (fot. Michał Murawski)

Fig. 3. Museum of the Altar of Peace in Rome, mosaic Ara Pacis, auth. Mimmo Paladino, 2000 (photo by Michał Murawski)

między antagonizmami (ciepły/zimny, zbity/rozproszony) dzięki kalibracji koloru. Wszystkie znaki zdaniem włoskiego kuratora mają wskazywać na ideę fragmentu, odsyłać do braków i niepełności. Tym samym sytuują się w horyzoncie zainteresowań artystycznych Paladino, którego sztuka często podejmuje temat kompensacji, suplementacji, uzupełniania nieobecnego (Oliva, 2008). W 2013 roku na forach rzymskich zostają wystawione prace wiodących włoskich artystów sztuki współczesnej (Arte contemporanea ai Fori Romani..., 2013). Forom, które w przeszłości pełniły rolę wystawienniczą, zostaje przywrócona jedna z pierwotnych funkcji. Dzieła, które mediują z przeszłością, zostają zanurzone w dziedzictwie starożytnym, co tworzy idealne warunki do budowania usytuowanego doświadczenia przeszłości. Od 2010 roku Alfred Seiland fotografuje topowe stanowiska archeologiczne, oddając pustkę, przemijanie, jednoczesną degradację i kapitalizację dziedzictwa. Jego zdjęcia zostają wystawione w wiedeńskiej Albertinie w 2018 roku (Seiland, 2018). Od 2015 roku w muzeum Johna Soane'a odbywają się czasowe wystawy sztuki współczesnej, podczas których swoje prace prezentują Sarah Lucas (Lucas, 2013) czy Marc Quinn 
(Quinn, 2017). Podczas wystawy Quinna w 2017 roku do chaotycznej przestrzeni muzeum Soane'a zostają wprowadzone niepokojące, pozbawione kończyn gipsowe akty (ryc. 4). Oryginalne artefakty służą jako tło dla sztuki współczesnej, wydobywając fragmentaryczny charakter prac.

Zamiast zatem koncentrować się na klasycznych pracach, które potrafiły archeologię traktować jako ironiczny przedmiot odniesienia (jak w przypadku twórczości Smithsona), być może szansą na pełniejszy rozwój perspektyw na styku archeologii i sztuki byłoby obserwowanie tego styku w rzeczywistości w muzealnych galeriach, gdzie porządek sztuki współczesnej zderza się z realiami archeologii. Przy założe-

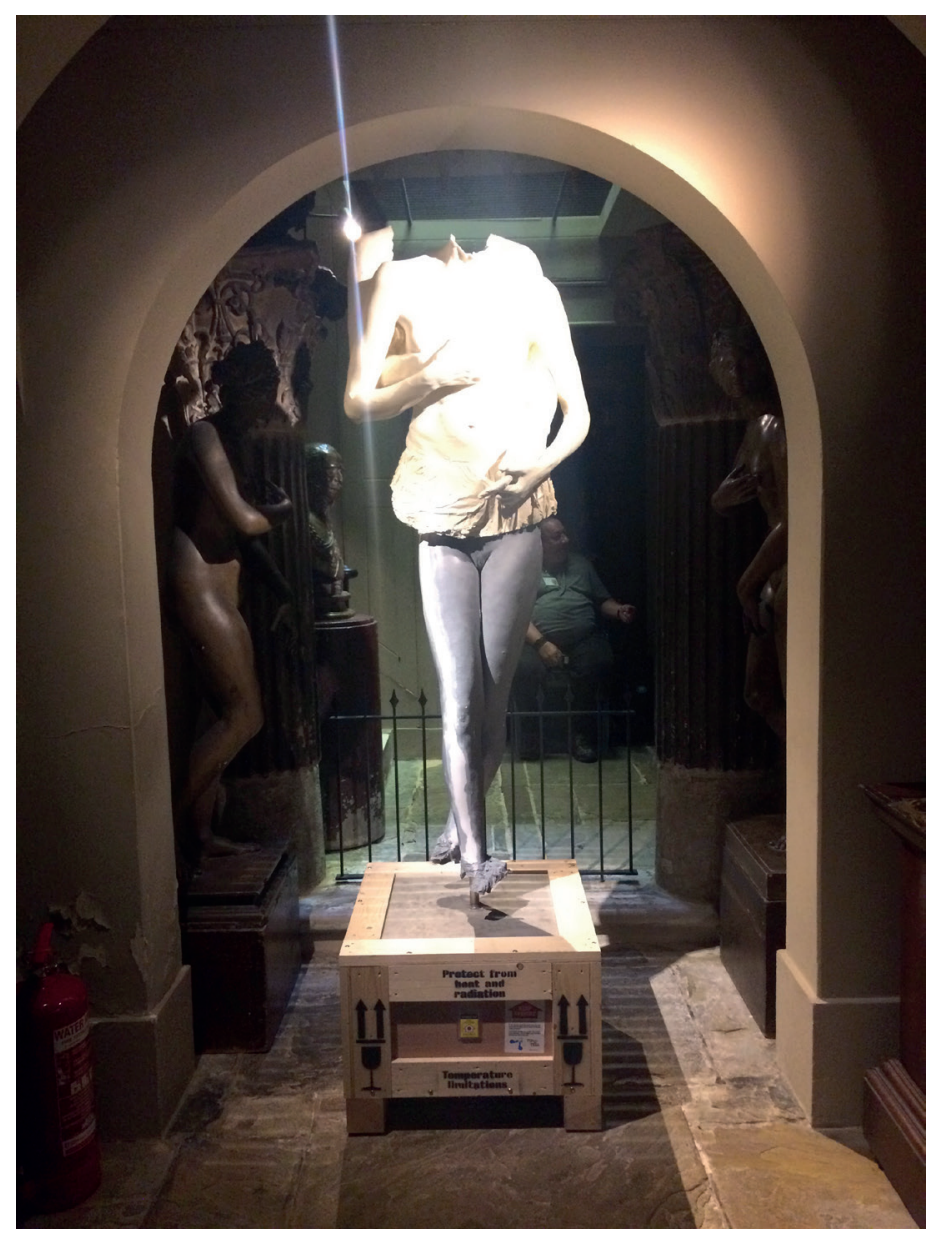

Ryc. 4. John Soanne's Museum w Londnynie, wystawa Marka Quinna Drawn from life, 2017 (fot. Monika Stobiecka)

Fig. 4. John Soanne's Museum in London, exhibition of Mark Quinn Drawn from life, 2017 (photo by Monika Stobiecka) 
niu, że zestawione z artefaktami prace artystów wzbudzają afekty i zainteresowanie, uzupełniają, komentują i metaforyzują doznanie przeszłości, tworzy się szansa na inaugurowanie nowych pól badawczych w ramach archeologii i sztuki, zaś wystawy mediujące $\mathrm{w}$ tym obszarze, w myśl przepływu wiedzy między akademią a muzeum, mogą stanowić ważny krok w stronę legitymizacji tych, często marginalnych badań, w oficjalnych curriculach uniwersyteckich.

\section{WYZWANIA METODOLOGICZNE}

Mimo gorących debat na styku archeologii i sztuki w literaturze nie pojawiły się dotychczas wyczerpujące studia metodologiczne odpowiadające na pytanie, jak prowadzić badania na styku archeologii i sztuki. Rodney Harrison i John Schofield, za Colinem Renfrew, powtarzają, że sztuka współczesna może pomóc archeologom w zrozumieniu przeszłości, badaniu relacji między człowiekiem a środowiskiem i analizowaniu kultury materialnej w nieszablonowy sposób (Harrison, Schofield, 2010, s. 109). Krótko zarysowują przy tym trzy główne trajektorie badań artystyczno-archeologicznych, które, o ile mi wiadomo, stanowią jedyną dość zwartą propozycję metodologiczną dostępną w literaturze przedmiotu.

Harrison i Schofield w pierwszej kolejności proponują, aby traktować dzieło sztuki jako obiekt archeologiczny (art as an archaeological record). Badanie dzieł sztuki w perspektywie archeologii sztuki ilustrują analizami prac Anselma Kiefera Nigredo (1984) i projektem La Ribaute (od 1992). Sugerują przy tym, że idea dosłownego eksplorowania obrazu jako stanowiska archeologicznego, dokumentowanie wyników wykopalisk w celu lepszego zrozumienia struktury obrazu mają potencjał do tego, aby stworzyć wspólny grunt dla archeologów i historyków sztuki poszukujących alternatyw badawczych (Harrison, Schofield, 2010, s. 110).

Kolejną metodą jest badanie praktyk archeologicznych jako performensu (archaeological investigation as a performance), które ma zwrócić uwagę na wymiar archeologii jako sztuki. Tę propozycję ilustrują wspomniane już projekty Marka Diona, który rekonstruuje warsztat archeologa w swoich pracach Tate Thames Dig i New England Dig.

Trzecie ujęcie proponowane przez Harrisona i Schofielda to strategia sztuki jako interpretacji, narracji i charakterystyki (art as an interpretation, narrative, and characterization), w której badacze zestawiają prace Lucy Orty All In One Basket (1997) i Hortirecycling (1999) z projektem naukowym „Tucson Garbage Project” prowadzonym przez Williama Rathje w latach 80. (zob. Rathje, 2004). Pokazując wartości i idee wspólne dla dzieł Orty i wyników badań Rathje (marnotrawstwo, intensywna konsumpcja), Harrison i Schofield udowadniają, jak tematy archeologów i artystów mogą się przenikać i wzajemnie uzupełniać.

Interesującą propozycję metodologiczną uzupełniłabym też o aspekt „zwrotny”. Przeniosłabym ciężar z tego, co archeologia może zyskać w kontakcie ze sztuką, krytyką i historią sztuki i zwróciła uwagę na to, jak historia i krytyka sztuki mogą sko- 
rzystać z tego archeologicznego mariażu. Postuluję zatem, aby nie tylko zauważać wspólne wątki i przedmioty zainteresowań czy konstatować, że sztuka porusza się w rejestrze archeologii, ale mocno zaznaczyć to, ile twórczych i kreatywnych impulsów może przynieść archeologia w interpretacji sztuki. Sugeruję w tym miejscu, że pożądane byłoby nie tyle otwarcie archeologów na historię sztuki i jej przedmioty zainteresowań, które przecież od lat uwidacznia się w literaturze, ale wyjście historyków i krytyków sztuki w stronę archeologii, zwrócenie uwagi na to, jak ta dyscyplina i jej metody badań oraz obiekty studiów mogą poszerzyć dotychczasowe analizy i interpretacje dzieł artystów. Innymi słowy zachęcić do postawienia pytania o to, co archeologia w rzeczywistości może dać historii i krytyce sztuki?

Jak pisał Mitchell, obserwujemy masowy zwrot ku „zwykłym rzeczom”, które stają się tematami studiów historyczno-artystycznych: ,«rzecz» podnosi głowę - to dzika bestia lub potwór rodem z science fiction, powrót wypartego, uparta materialność, blokada, lekcja, jaką daje nam przedmiot" (Mitchell, 2013). Jakie lekcje dają zatem przedmioty historykom sztuki? Jak słusznie punktuje Mitchell, to lekcje z idolatrii, fetyszyzacji i totemizacji (Mitchell, 2013), przed którymi archeologów ostrzegali w latach 90. Shanks i Tilley. Czy jednak na tym wyczerpuje się potencjał rzeczy? Jak sądzę, odpowiedzi na to pytanie mogą udzielić badaczom sztuki i kultury wizualnej archeolodzy, „badacze starych rzeczy” (Olsen i in., 2012).

Obserwując współczesną scenę artystyczną w Polsce i realizowane tu projekty, mam wrażenie, że zaangażowanie perspektyw archeologicznych w badanie sztuki byłoby najbardziej pożądanym w kontekście poszerzania i niuansowania interpretacji. Być może traktowanie dzieła sztuki jako stanowiska archeologicznego (Harrison, Schofield, 2010) nie jest jednak jedyną możliwością czerpania z warsztatu badawczego archeologów. Posiłkowanie się archeologicznymi metaforami (González-Ruibal, 2013; por. Pollock, 2006), poetyką praktyki archeologicznej czy odniesieniem do ontologii artefaktu jako znaleziska ewokujące surrealistyczne i dadaistyczne objets trouvées, innymi słowy pełne korzystanie $\mathrm{z}$ archeologicznej wyobraźni (Shanks, 2012) gwarantuje szersze możliwości poznawcze i interpretacyjne. Tym samym, proponując taką metodę badania prac artystycznych, odwracam pytanie sparafrazowane za Mitchellem i pytam o to, czy dzieła sztuki chcą być artefaktami?

Odnoszę się w tym miejscu do szeregu współczesnych prac, które dzięki zderzeniu z narzędziami metodologicznymi archeologów zyskałyby na interpretacyjnym impecie. Mowa tu między innymi o pracy Ai Weiweia w bródnowskim Parku Rzeźby, w ramach której artysta rozbił kopię wazy dynastii Yuan na kilkaset fragmentów, a te następnie zdeponował w trzech wykopanych w ziemi głębokich dołach (Weiwei, 2014). Do odnalezienia (To be found) z 2014 roku, interpretowane głównie w odniesieniu do archiwum Ringelbluma, w zderzeniu z archeologicznym słownikiem zyskałoby na pogłębionym znaczeniu. Projekt można byłoby rozpatrywać jako prefigurację dziedzictwa przyszłości, spekulację nad tym, jakie artefakty zostawiamy po sobie my, współcześnie stąpając po ziemi. W podobnym duchu można byłoby potraktować pracę Huberta Czerepoka prezentowaną na wystawie Początek w Zachęcie Narodowej Galerii Sztuki (Czerepok, 2017) i wystawie Porzadek w Galerii SKALA(Wasilewski, 
2019), w której artysta dokumentuje Karahan Tepe w Turcji. Niemalże marsjański łazik, który przemierza stanowisko archeologiczne, zachęca do myślenia o diachronicznym spotkaniu przeszłości i przyszłości.

Innym możliwym kierunkiem dla pogłębienia interpretacji mogą być projekty, w których artyści skupiają się na przeobrażającej się tkance obiektów - Wodnik Joanny Rajkowskiej (Rajkowska, 2009) czy Tężnia Roberta Kuśmirowskiego (Jarecka, 2015). Artyści obserwują przemiany materii pod wpływem czynników zewnętrznych - pogody, wietrzenia, kontaktu z wodą. Ich prace tym samym zbliżają się do odtwarzania procesu stawania się artefaktem, śledzenia ,życia artefaktu” (Shanks, 1998). Praca Kuśmirowskiego, zestawiona z klasykiem polskiej sztuki współczesnej Tadeuszem Kantorem i jego przedmiotami „biednymi” (Domańska, 2008), mogłaby również otworzyć krytyczne rozważania na temat statusu pozostawionych zwykłych rzeczy, które w zderzeniu z poetyką archeologii zyskałyby na dodatkowym wymiarze interpretacyjnym.

W 2017 roku Agnieszka Kalinowska prezentuje pracę Ciężka woda. Intencją artystki jest odtworzenie dzbanów na wodę znanych z regionów, z których obecnie migrują ludzie. Skupiając się na kryzysie uchodźczym, Kalinowska powołuje się na wyniki badań archeologicznych, które wskazują, że naczynia na wodę i żywność markują kierunki migracyjne (Kalinowska, 2017). W 2018 roku Agata Ingarden, polska artystka działająca w Paryżu, wystawia kilka fragmentów wylewów amfor z brzuścami. Naczynia przygotowuje w taki sposób, że przepływające przez nie powietrze generuje dźwięki. Mówiace amfory (Talking amphores), z których każda opowiada inną historię, wskazują na wielość interpretacji przeszłości mediowanych przez szept naruszonej materii ${ }^{4}$.

Obserwowalny wzrost popularności wątków archeologicznych wśród artystów współczesnych powinien być zachętą już nie tylko dla archeologów, ale dla badaczy sztuki. Dotychczas wybiegi w stronę archeologii w Polsce czyniła jedynie Magdalena Wróblewska, śmiało korzystając z teorii Bjørnara Olsena (Wróblewska, 2014). Prace te $\mathrm{z}$ drugiej strony zachęcają też do wystawienniczych eksperymentów odbywających się już w muzeach archeologicznych w wielu krajach - wprowadzania dzieł sztuki współczesnej do tradycyjnych narracji archeologicznych. Swoiste mediacje artystyczne w archeologii byłyby ciekawą alternatywą dla wystawiennictwa archeologicznego w Polsce.

\section{ARCHEOLOGIA OBCYCH. POMIĘDZY ARCHEOLOGIĄ, SZTUKĄ A PRZEWIDYWANIEM PRZYSZLOŚCI}

Przykładem, którym pragnę zilustrować prezentowane tu tezy i życzenia dla badań na styku archeologii i sztuki, uczynię pracę Agnieszki Kurant Archeologia obcych z 2019 roku. Praca została zaprezentowana na wystawie Bezludzka Ziemia odbywa-

\footnotetext{
${ }^{4}$ Materiały udostępnione dzięki uprzejmości artystki.
} 
jącej się w warszawskim Centrum Sztuki Współczesnej od marca do września 2019 roku. Wystawa jest jednym z efektów projektu Plastyczność planety, który kieruje się ku zagadnieniom pandemii, kataklizmu i antropocenu.

Praca Archeologia obcych (ryc. 5) to niewielkich rozmiarów piramida wykonana z bezoarów, kamieni znajdowanych w żołądkach i jelitach ludzi i zwierząt. Te obłe i nieregularne w kształcie kamienie tworzą się w wyniku zbierania się resztek pożywienia w układzie pokarmowym. Bezoary przez wieki były uznawane za kamienie magiczne o właściwościach leczniczych. Oprawione w złoto zdobiły królewskie głowy. Do dziś ich ceny mogą konkurować z cenami kamieni szlachetnych, choć udowodniono, że nie mają żadnych mocy uzdrawiających. Praca Kurant korzysta z bezoarów pochodzących z żołądków tygrysa, nosorożca, lamy, żyrafy, kóz, gęsi i jeżozwierzy. Ustawiona w szeregu z innymi skamielinami przyszłości (Mutacje i plynne aktywa, Martwa natura, Postfordyt, Skamieniała przyszlość) stanowi sztuczne fosylium prowokujące do pytania o to, co uznajemy za dziedzictwo przyszłości.

Archeologia przyszłości wpisuje się w dotychczasowe zainteresowania Agnieszki Kurant, artystki i kuratorki. W swoich poprzednich projektach Kurant interesowała się przede wszystkim materialnością, relacją między tym, co namacalne a niewidzialne. Jej konceptualne prace najbliższe są idei „dzieła otwartego” (Kurant, 2020), a częste sięganie do nurtu art and science, jak choćby w pracach Political Weather (2010) czy Symfonia Tesli (2007-2009), lokuje jej twórczość na interdyscyplinarnym styku. Artystka równie często kontestuje działanie rynku sztuki, poddając refleksji realne wartości prac artystycznych.

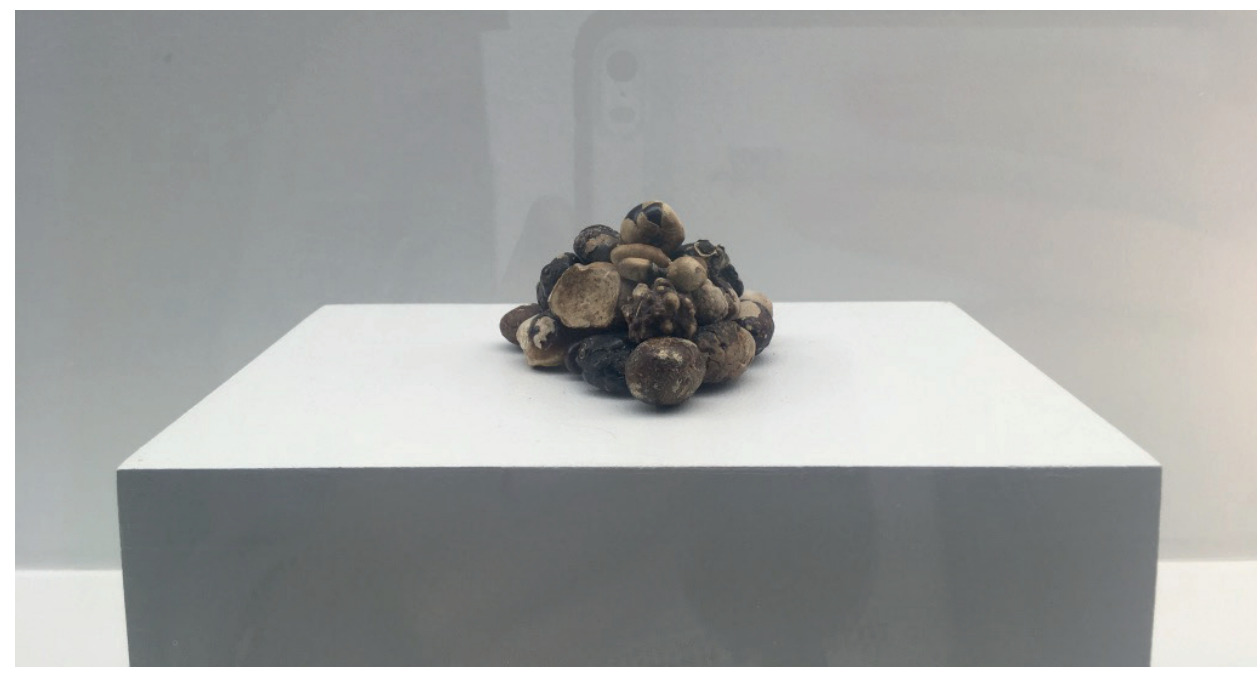

Ryc. 5. U-jazdowski Centrum Sztuki Współczesnej w Warszawie, wystawa Bezludzka Ziemia, Agnieszka Kurant, Archeologia obcych, 2019 (fot. Monika Stobiecka)

Fig. 5. U-jazdowski Center of the Modern Art in Warsaw, exhibition Bezludzka Ziemia, Agnieszka Kurant, Archeologia obcych, 2019 (photo by Monika Stobiecka) 
Praca prezentowana w warszawskim CSW skłania mnie do ponownego postawienia pytania kluczowego dla tego tekstu: czy dzieło sztuki chce być artefaktem? Dzieło sztuki w tym przypadku bezpardonowo wkracza w obszar archeologii bezpośrednio przez tytuł, jak i piramidalną formę odwołującą do repertuaru symboli archeologii, który zdaniem Shanksa motywuje do odkrywania i sondowania przeszłości (Shanks, 2012). Ten motyw archeologiczny tak ulubiony przez kulturę popularną (filmy utrzymane w nurcie egiptomanii «Hall, 1999», programy telewizyjne o pseudoarcheologicznym charakterze, np. Starożytni kosmici) mógłby zapewne wywołać falę oburzenia po stronie archeologów, podobną do tej, którą zesłał na siebie Damien Hirst, prezentując Skarby z wraku Niemożliwego (Greene, Leidwanger, 2017). Niemniej zarówno w pracy Kurant, jak i w pracy Hirsta do głosu dochodzi potęga i moc archeologicznych wizerunków i skojarzeń. Piramidalna konstrukcja bezoarów jest nieśmiertelna, przetrwa wieki, podobnie jak monumentalne konstrukcje z Gizy, stanowiące dla wielu największe tajemnice skrywane przez przeszłość. W sposób oczywisty zatem Kurant nawiązuje dialog z pojęciami kluczowymi dla archeologów - czasem i materią, pytając o to, co pozostanie po współczesności. Kurant spekuluje nad kulturą materialną, prowadząc swoistą futurologię, która zbliża jej projekt do cytowanych prac Ai Weiweia czy Huberta Czerepoka.

Praca Kurant ponadto w interesujący dla mnie sposób wykracza poza estetyczne poszukiwania piękna typowe dla części przedstawicieli nurtu badań na styku archeologii i sztuki. Archeologia obcych jest usytuowana w obszarze estetyki antropocenu (Davis, Turpin, 2015) i sonduje granicę między tym, co naturalne, a co kulturowe. Przez użycie bezoarów, naturalnych kamieni ludzko-nieludzkich, uformowanych w pracy na kształt piramidy, praca kontestuje ten arbitralny rozdział między naturą i kulturą, mówiąc nam, że dziedzictwo przyszłości jest efektem scalenia tych dwóch sił.

Praca nabiera również interesującego znaczenia, gdy rozpatrzy się ją jako ,pomnik antropocenu" (Praczyk, 2017; Szerszyński, 2018). Pojęcie to odnosi się do dyskusji na temat „kultu pomników” i potrzeby konceptualizowania monumentu antropocenu. Traktując pracę Kurant jako „,pomnik antropocenu”, dostrzegam w niej próbę połączenia trzech istotnych dyskursów formujących debaty na temat nowej epoki w dziejach Ziemi: geologicznego, ekohumanistycznego i archeologicznego. Archeologia obcych ustawiona w ciągu z innymi skamielinami przeszłości oddaje perspektywę długiego trwania i nieludzkich skal czasowych. Te zdaniem Moniki Bakke (Bakke, 2016) ujawniają wpływ naturalnych organizmów na mineralne środowisko. Formowanie się skamielin jest w istocie długotrwałym procesem, ,wynikającym z życia" (Bakke, 2016, s. 62). Użyte do zbudowania tego pomnika bezoary są faktycznie produktami procesów życiowych - metabolizacji. Jednocześnie, łącząc to, co naturalne i to, co kulturowe, praca Kurant w oczywisty sposób wkracza też w obszar dyskusji ekohumanistycznych.

Bronisław Szerszyński twierdzi, że w ideę pomnika wpisane jest popadanie w ruinę, powolna, nieludzka destrukcja (Szerszyński, 2018, s. 286), która sprzyja monumentalizacji - w istocie nie pomnika, ale ludzkiego czynu powołującego monument do życia. Kurant odwraca zatem ideę pomnika, tworząc przeciwpomnik (Young, 2000), 
niewielki, drobny obiekt, a jednak materialny dowód, antropoceniczny ślad. Na poziomie dialogu $\mathrm{z}$ archeologią, realizacja artystki mieści się $\mathrm{w}$ debatach dotyczących roli tej dyscypliny w badaniu antropocenu (por. Stobiecka, 2018, 2019), sondowaniu cezury otwierającej antropocen, negocjowaniu obszarów zaangażowania archeologów, przewidywaniu scenariuszy przyszłości przez analizowanie reakcji przeszłych społeczeństw na kryzysy klimatyczne i klęski środowiskowe. Kurant preparuje zatem sztuczny artefakt antropocenu, obiekt, który w przyszłości mógłby zaświadczać o współczesności, stanowiąc przedmiot badań.

Czy zatem potencjał tkwiący w tej i innych cytowanych pracach nie byłby ożywczy choćby dla polskich muzeów archeologicznych? Co przyniosłoby studiom zestawienie takiej pracy z tradycyjnymi przedmiotami badań archeologii? Czy legitymizowałoby Archeologie obcych jako prawdopodobny scenariusz dla kultury materialnej w przyszłości? Czy wreszcie, w zderzeniu z rzeczywistymi znaleziskami, praca $\mathrm{Ku}$ rant stałaby się artefaktem, którym, jak przypuszczam, chciałaby być?

\section{WNIOSKI. ARTYSTYCZNE MEDIACJE}

Dotychczasowy dorobek badań archeologicznych nad sztuką pozwala sądzić, że studia te nadal będą rozwijane, przynosząc archeologom więcej inspiracji poprzez artystyczne mediacje. Szczególnie przytaczane projekty Douga Bailey’a ilustrują moim zdaniem największe korzyści dla wprowadzania sztuki do warsztatu archeologa. Wyobraźnia artystyczna poszerza możliwości wyobraźni archeologicznej. Stymuluje badaczy do nieoczywistych interpretacji, alternatywnego spojrzenia na artefakty i stanowiska. Spośród zarysowanych tu horyzontów to właśnie kierunek Bailey’a wydaje mi się najbardziej interesujący i pełen potencjału dla ożywiania, animowania, badania artefaktów przez zderzenie ze sztuką. Wyzwania nie stanowi moim zdaniem doszukiwanie się przez archeologów analogii między artefaktami i stanowiskami a pracami artystów, ale raczej próba negocjowania między archeologią a sztuką (por. Nycz, 2017), stawianie pytań o to, co faktycznie przynosi sztuka archeologii stanowiskom czy artefaktom? Jak poszerza nasze możliwości poznawcze? Czy i jak pozwala lepiej rozumieć przeszłość?

Z powyższych rozważań płyną również wnioski na przyszłość dla przede wszystkim dwóch obszarów: wystawiennictwa archeologicznego i badań nad sztuką. To właśnie w muzeach i w krytyce artystycznej powinny ogniskować się najbardziej radykalne przemiany. Biorąc pod uwagę zainteresowanie archeologów sztuką współczesną, legitymizacji tej fascynacji należałoby szukać w muzealnych galeriach. Obserwowanie styku między archeologią i sztuką wydaje się najciekawsze w rzeczywistości muzealnej. Zderzanie porządku sztuki współczesnej i archeologii pozwala również rewidować dotychczasowe relacje między tymi dwoma obszarami, zwłaszcza długotrwałą tradycję prezentowania artefaktów jako dzieł sztuki. Ta moim zdaniem nie wymaga odrzucenia, ale właśnie rewizji i uwspółcześnienia, które stają się możliwe w dobie rosnącego zainteresowania artystów przeszłością, 
materialnością, fragmentaryzacją, rujnacją i archeologią. Tak obciążająca i opresyjna dla artefaktów relacja z paradygmatem artystycznym w wystawiennictwie prosi się o przepracowanie i konfrontację ze sztuką najnowszą, po którą sięgają coraz częściej archeolodzy w swoich studiach. Sztuka najnowsza bowiem wymyka się kantowskiej estetyce piękna i wzniosłości, żąda od oglądających zaangażowania, interakcji, porusza się w estetyce codzienności (Saito, 2007), abiektu (Kristeva, 2007), fragmentu (Simmel, 2006), ruin (Edensor, 2005; Olsen, Pétursdóttir, 2014), antropocenu (Davies, Turpin, 2015), nowego materializmu (Parikka, 2015). To najnowsza sztuka i jej estetyka zdolna jest zatem obalić specyficzny paradygmat estetyczny, który został narzucony na artefakty w muzeach archeologicznych, a wiąże się z klasycznymi kategoriami estetycznymi.

Drugie wyzwanie, które wynika z rozwoju horyzontu badań nad archeologią i sztuką, jest przede wszystkim skierowane do badaczy sztuki. Archeolodzy wybiegają w kierunku badań nad kulturą wizualną, estetyką czy sztuką współczesną. Brak jednak takiej inicjatywy ze strony badaczy sztuki, wyjścia w kierunku metod i interpretacji archeologicznych, głównych paradygmatów i teorii. W dobie tak podkreślanego przez wielu tu cytowanych archeologów zwrotu ku rzeczom nieszczególnie widoczne są mariaże innych dyscyplin humanistycznych $\mathrm{z}$ archeologią. Jak udowodniła w swoich badaniach Wróblewska, to narzędzia archeologiczne pozwoliły historyczce sztuki przełamać reżim wizualny fotografii. Może w takim razie należy powtórzyć wcześniej zadane pytanie, tym razem kierując je bezpośrednio do historyków i krytyków sztuki: a co, jeśli obrazy chcą być artefaktami?

\section{Podziękowania}

Uprzejmie dziękuję za wszystkie ważne i cenne komentarze do tekstu prof. dr hab. Ewie Domańskiej, a prof. dr hab. Marii Poprzęckiej za inspirujące rozmowy o obszarze sztuki i archeologii. Za inspiracje i istotne uwagi dziękuję także uczestnikom konferencji „Archeologia - pamięć - sztuka” odbywającej się na Uniwersytecie Adama Mickiewicza i Uniwersytecie Artystycznym w Poznaniu w dniach 21-23 marca 2019 roku.

\section{BIBLIOGRAFIA}

Arte contemporanea ai Fori Romani. Tutte le foto in anteprima della mostra Post-classici, il video-speach con il curatore. E un appello al Ministro Bray

2013, 21 marca Arttribune. Pobrano z: http://www.artribune.com/tribnews/2013/05/arte-contemporanea-ai-fori-romani-tutte-le-foto-in-anteprima-della-mostra-post-classici-il-video-speach-

Bailey, D. -con-il-curatore-e-un-appello-al-ministro-bray/

2017a Art/Archaeology: What Value Artistic-Archaeological Collaboration? Journal of Contemporary Archaeology, 4(2), 246-256. 
2017 b Disarticulate - Repurpose - Disrupt: Art/Archaeology. Cambridge Archaeological Journal, 27(4), 691-701.

2018 Breaking the surface. An Art/Archaeology of Prehistoric Architecture. Oxford: Oxford University Press.

Bakke, M.

2016 Geologizing the Present. Making Kin with Mineral Species and Inhuman Forces. W: B. Ermacora, H. Hirsch, M. Holzhey (red.), The Forces behind the Forms: Geology, Matter, Process in Contemporary Art (s. 59-67). Köln: Snoeck.

Belting, $\mathrm{H}$.

2003 Art History after Modernism. Przekł. C. Saltzwedel, M. Cohen, K. Northcott. Chicago London: The University of Chicago Press.

Bonaventura, P., Jones, A.

2011 Shaping the past: sculpture and archaeology. W: P. Bonaventura, A. Jones (red.), Sculpture and archaeology (s. 1-21). Surrey - Burlington: Routledge.

Bonaventura, P., Jones, A. (red.)

2011 Sculpture and Archaeology. Surrey - Burlington: Routledge.

Bugaj, E.

2003 Problemy interpretacji zjawisk sztuki w archeologii w kontekście nieoczywistości sztuki. W: B. Gediga, A. P. Kowalski (red.), Estetyka w archeologii (s. 11-20). Gdańsk: Muzeum Archeologiczne w Gdańsku.

2004 Badania archeologiczne a obrazowanie wizualne przeszłości. W: B. Gediga, W. Piotrowski (red.), Archeologia - Kultura - Ideologie (s. 253-263). Biskupin - Wrocław: PAN Oddział we Wrocławiu, Muzeum Archeologiczne w Biskupinie, IAiE PAN.

2012 Archeologia a sztuka. W: S. Tabaczyński, A. Marciniak, D. Cyngot, A. Zalewska (red.), Przeszłość społeczna. Próba konceptualizacji (s. 885-909). Poznań: Wydawnictwo Poznańskie.

Chittock, H., Valdez-Tullett, J.

2016 Archaeology with Art: A short introduction to this book. W: H. Chittock, J. Valdez-Tullett (red.), Archaeology with Art (s. V-VIII). Oxford: Archaeopress.

Currie, G.

2012 The Master of the Masek Beds: Handaxes, Art, and the Minds of Early Humans. W: E. Schellekens, P. Goldie (red.), The Aesthetic Mind: Philosophy and Psychology (s. 9-31). Oxford - New York: Oxford University Press.

Czerepok, H.

2017 ,

16 września- Początek. Pobrano z: https://zacheta.art.pl/pl/wystawy/hubert-czerepok-poczatek?fil19 listopada ters=eyJpZCI6WyIzMjE3IiwiMzIxNSIsIjMyMTMiXSwib3JkZXIiOiJGSUVMRCAoaWQsMzIxNywzMjE1LDMyMTMpIn0\%3D

Danielsson, I.-M., Fahlander, F., Sjöstrand, Y. (red.)

2012 Encountering imagery: materialities, perceptions, relations. Stockholm Studies in Archaeology, 57. Stockholm: Stockholm University.

Deshoulières, V. A.

2014 La voix d'Arkhè: le paradigme archéologique dans la création moderne et contemporaine. Paris: Hermann.

Davis, H., Turpin. E. (red.)

2015 Art in the Anthropocene. Encounters Among Aesthetics, Politics, Environments and Epistemologies. London: Open Humanities Press.

Domańska, E.

2008 Humanistyka nie-antropocentryczna a studia nad rzeczami. Kultura współczesna, 3, s. 9-21. 
Edensor, $\mathrm{T}$.

2005 Industrial ruins: spaces, aesthetics, and materiality. Oxford: Berg.

Flam, J. (red.)

1996 Robert Smithson, the collected writings. Berkeley - Los Angeles - London: University of California Press.

Folga-Januszewska, D.

2015 Muzeum: fenomeny i problemy. Kraków: Universitas.

Gell, A.

2013 Art and Agency: an anthropological theory. Oxford: Claredon.

González-Ruibal, A.

2013 Reclaiming Archaeology. W: A. González-Ruibal (red.), Reclaiming Archaeology Beyond the Tropes of Modernity (s. 44-55). London - New York: Routledge.

Gosden, Ch.

2001 Making sense: archaeology and aesthetics. World Archaeology, 33(2), 163-167.

Greene, E., Leidwanger, J.

2017 Damien Hirst's Tale of a Shipwreck and Salvaged Treasures. American Journal of Archaeology, 1(122), 2-11.

Hamilakis, Y.

2013 Archaeology and the Senses. Human Experience, Memory, and Affect. New York: Cambridge University Press.

Harrison, R.

2011 Surface assemblages. Towards an archaeology in and of the present. Archaeological Dialogues, 18(2), 141-161.

Harrison, R., Schofield, J.

2010 After Modernity. Archaeological Approaches to the Contemporary Past. Oxford: Oxford University Press.

Jameson, J. M.

2003 Art and Imagery as Tools for Public Interpretation and Education in Archaeology. W: J. M., Jameson, J. E. Ehrenhard, Ch. A., Finn (red.), Ancient muses: archaeology and the art (s. 57-65). Tuscaloosa - London: The University of Alabama Press.

Jameson, J. M., Ehrenhard, J. E., Finn, Ch. A. (red.)

2003 Ancient muses: archaeology and the art. Tuscaloosa - London: The University of Alabama Press.

Jarecka, D.

2015 ,

19 listopada 'Tężnia”, czyli pamięciologia zastosowana. Czemu pod CSW stoi magazyn pełen śmieci i zabytków? Pobrano z: http://wyborcza.pl/1,75410,19210709,teznia-czyli-pamieciologia-

Jones, A., Bonaventura, P.

-zastosowana-czemu-pod-csw-stoi.html

2011 Shaping the past: sculpture and archaeology. W: P. Bonaventura, A. Jones (red.), Sculpture and Archaeology (s. 1-17). Surrey - Burlington: Routledge.

Kalinowska, A.

2017 ,

3 października Ciężka woda. Pobrano z: http://opencity.pl/program/agnieszka-kalinowska

Kobiałka, D.

2017 Sztuka okopowa. Archeologia Żywa, 1(63), 76-80.

Kowalski, H.

2008 Antyczne tradycje w dekoracji rzeźbiarskiej gmachów Uniwersytetu Warszawskiego przy Krakowskim Przedmieściu. Warszawa: Wydawnictwa Uniwersytetu Warszawskiego. 
Kristeva, J.

2007 Potęga obrzydzenia. Esej o wstręcie. Przekł. M. Falski. Kraków: Wydawnictwo Uniwersytetu Jagiellońskiego.

Kurant, A.

2020, Pobrano z: https://culture.pl/pl/tworca/agnieszka-kurant

7 marca

Lucas, $\mathrm{S}$.

2016 Power in Woman. Pobrano z: https://www.soane.org/whats-on/exhibitions/sarah-lucas-power-woman

Minta-Tworzowska, D.

2017 Świat kolorów ludzi paleolitu jako element intertekstualności „obrazów” w jaskiniach.

Folia Praehistorica Posnaniensia, 22, 111-142.

Mitchell, W. J. T.

2013 Czego pragna obrazy? Pragnienia przedstawień, zycie i miłości obrazów. Przekł. Ł. Zaremba. Kraków: Międzynarodowe Centrum Kultury. [Wersja e-book]

Miziołek, J.

2005 Uniwersytet Warszawski. Dzieje i tradycja. Warszawa: Wydawnictwa Uniwersytetu Warszawskiego.

2007 Villa Laurentina. Arcydzieło epoki stanisławowskiej. Warszawa: Biblioteka Narodowa.

Nycz, R.

2017 Kultura jako czasownik. Sondowanie nowej humanistyki. Warszawa: Wydawnictwo Instytutu Badań Literackich PAN.

Oliva, A. B.

2008 Ara Artis. Pobrano z: http://en.arapacis.it/mostre_ed_eventi/mostre/opera_per_1_ara_pacis_mimmo_paladino_brian_eno/ara_artis

Olsen, B.

2013 W obronie rzeczy. Archeologia i ontologia przedmiotów. Przekł. B. Shallcross. Warszawa: Instytut Badań Literackich PAN.

Olsen, B., Pétursdóttir, P. (red.)

2014 Ruin Memories. Materiality, Aesthetics and the Archaeology of the Recent Past. LondonNew York: Routledge.

Olsen, B., Shanks, M., Webmoor, T., Witmore, Ch.

2012 Archaeology. The Discipline of Things. Berkeley - Los Angeles - London: University of California Press.

Parikka, J.

2015 Contemporary Land Arts, Technology and New Materialist Aesthetics. Cultural Studies Review, 21(2), 47-75.

Pearson, M., Shanks, M.

2001 Theatre/Archaeology. London - New York: Routledge.

Pollard, J.

2004 The art of decay and the transformation of substance. W: C. Renfrew, Ch. Gosden, E. DeMarais (red.), Substance, memory, display: archaeology and art (s. 47-62). Cambridge:

Pollock, G. McDonald Institute for Archaeological Research.

2006 The Image in Psychoanalysis and the Archaeological Metaphor. W: G. Pollock (red.), Psychoanalysis and the Image. Interdisciplinary Perspectives (s. 1-29). Malden - Oxford - Victoria: Blackwell Publishing.

Poprzęcka, M.

2019 Impas. Opór, utrata, niemoc, sztuka. Gdańsk: Fundacja Terytoria Książki.

Praczyk, M. (red.)

2017 Pomniki w epoce antropocenu. Poznań: Wydawnictwo Naukowe UAM. 
Quinn, M.

2017 Drawn from Life. Pobrano z: https://www.soane.org/whats-on/exhibitions/marc-quinn-drawn-life

Rajkowska, J.

2018, Wodnik. Pobrano z: http://www.rajkowska.com/pl/projektyp/77

25 lipca

Ramos, M., Duganne, D.

2000 Exploring Public Perceptions and Attitudes about Archaeology. Pobrano z: http://www. nps.gov/archeology/pubs/Harris/index.htm

Rathje, W. 2004

Renfrew, C.

1999 It may be art but is it archaeology? Science as art and art as science. W: M. Dion (red.), Mark Dion: archaeology (s. 12-23). London: Black Dog Publishing.

2003 Figuring it out. What are we? Where do we come from? The parallel visions of artists and archaeologists. London: Thames and Hudson.

2004 Art for Archaeology. W: C. Renfrew, Ch. Gosden, E. DeMarais (red.), Substance, memory, display: archaeology and art (s. 7-34). Cambridge: McDonald Institute for Archaeological Research.

2014 Colin Renfrew: A Conversation. W: I. A. Russel, A. Cochrane (red.), Art and Archaeology Renfrew, C., Bahn, P.

(s. 9-20). New York - Heidelberg - Dordrecht - London: Routledge.

2002 Archeologia: teorie, metody, praktyka. Przekł. M. Kasprzycka i in. Warszawa: Prószyński i S-ka.

Renfrew, C., Gosden, Ch., DeMarais E. (red.)

2004 Substance, memory, display: archaeology and art. Cambridge: McDonald Institute for Archaeological Research.

Roberts, J. L.

2004 Mirror-Travels. Robert Smithson and History. New Haven and London: Yale University Press.

Russell, I. A.

2011 Art and archaeology. A modern allegory. Archaeological Dialogues, 18(2), 172-176.

Russell, I. A., Cochrane, A. (red.)

2014 Art and Archaeology. New York - Heidelberg - Dordrecht - London: Routledge.

Saito, Y.

2007 Everyday Aesthetics. Oxford: Oxford University Press.

Seinland, A.

2018 Pobrano z: https://www.albertina.at/en/exhibitions/alfred-seiland/

Shanks, M.

1998 The Life of an Artifact in an Interpretive Archaeology. Fennoscandia Archaeologica, 15, $15-31$.

2012 The Archaeological Imagination. Walnut Creek: Left Coast Press.

Sjöstrand, Y.

2017 The Concept of Art as Archaeologically Applicable. Cambridge Archaeological Journal, 27(2), 371-388.

Simmel, G.

2006 Most i drzwi. Wybór esejów. Przekł. M. Łukasiewicz. Warszawa: Oficyna Naukowa.

Stobiecka, M.

2018 Archeologia antropocenu i cyfrowe krajobrazy. Prace Kulturoznawcze, 22, 145-163.

2019 Nomadyczne dziedzictwo. O migracjach rzeczy w przyszłość. Stan Rzeczy, 14, $135-155$. 
Swain, H.

2007 An Introduction to Museum Archaeology. Cambridge: Cambridge University Press.

Szerszyński, B.

2018 Monument antropocenu. Prace Kulturoznawcze, 22, 281-308.

Thomas, J.

2004 Archaeology and Modernity. London - New York: Routledge.

Tilley, Ch., Shanks, M.

1992 Re-Constructing Archaeology. Theory and Practice. London - New York: Routledge.

Vergo, $\mathrm{P}$.

2005 Milczący obiekt. W: M. Popczyk (red.), Muzeum sztuki. Antologia (s. 313-334). Kraków: Universitas.

Vergo, P. (red.)

1989 The New Museology. London: Reaktion Books.

Vickers, M.

1994 Aesthetics in archaeology. Cambridge Archaeological Journal, 4(2), 255-256.

Vilches, F.

2007 The art of archaeology. Mark Dion and his dig projects. Journal of Social Archaeology, $7(2), 199-223$.

2011 Mirrored practices: Robert Smithson and archaeological fieldwork. W: P. Bonaventura, A. Jones (red.), Sculpture and Archaeology (s. 97-112). Burlington: Routledge.

Warburg, A.

2016 Atlas Obrazów Mnemosyne. Przekł. P. Brożyński, M. Jędrzejczyk. Warszawa: Narodowe Centrum Kultury.

Wasilewski, M.

2019, Porzadek, Hubert Czerepok. Pobrano z: https://archeologiapamiecsztuka.pl/wystawy/po-

20 marca rzadek-2/

-12 kwietnia

Weiwei, A.

2014, To be found. Park Rzeźby na Bródnie. Rozdz. VI. Pobrano z: https://artmuseum.pl/pl/doc/ 13 lipca ai-weiwei-to-be-found

Welsch, W.

1997 Aesthetics beyond Aesthetics. Pobrano z: http://www2.uni-jena.de/welsch/papers/W_Wel-

Wróblewska, M. sch_Aesthetics_beyond_Aesthetics.html

2014 Fotografie ruin, ruiny fotografii 1944-2014. Warszawa: Muzeum Warszawy.

Young, J. E.

2000 At the Memory Edge. After-Images of the Holocaust In Contemporary Art. and Architecture. New Haven - London: Yale University Press.

\section{PERSPECTIVES AND CHALLENGES ON THE EDGE OF ARCHAEOLOGY AND ART}

\section{Sum mary}

Relations between contemporary art and archaeology have been the point of interest of many scholars researching the past. Although the transfer between art and archaeology is studied by such authorities as Colin Renfrew, Michael Shanks, Andrew Jones, Ian Russell, Paul Reilly or Paul Bonaventura, the art and archaeology based research still does not propose any systematic and coherent vision of how to conduct a research on the edge of art and archaeology. 
The perspective of a historian and archaeologist that is applied in the paper enables me to reflect on the challenges that appear in the research on the edge of art and archaeology, presenting the potential benefits of tightening the interdisciplinary cooperation, and also proposing remedies on the observed problems in methodology and definition. Archaeological museums are the basis for new theoretical and practical quests. They situate in the place where archaeology, art, and aesthetics meet. Referencing foreign exhibitions and the works of Polish artists allows presenting the potential scenarios of cooperation between archaeology and contemporary art.

Various terms used in the paper - archaeology, art, aesthetics - are understood in the following way: 1) archaeology - the discipline that studies the things from the past which aims to reconstruct the lives of past human beings and non-humans, and archaeology as a set of metaphors, the poetics of practice used by the representatives of other scientific disciplines; 2) art - in the institutional approach, it is everything that is called art by the institutional apparatus (critics, historians, art researchers, galleries, museum, and art market); 3) aesthetics - in the heterogenic approach as aesthetics - the perspectives which transgress Kant's aesthetics of beauty and loftiness, actualizing it by aesthetics of ugliness and abject, aesthetics of fragments and ruins, aesthetics of everydayness, Anthropocene, new materialism, new aesthetics.

The article is divided into six parts. In the first, I analyze the state of the art in the area of archaeology, art, and aesthetics - focusing on the main research points: reflection on aesthetic dimension of artifacts in the past, theoretical approaches confronting archaeological interpretations with contemporary art, and reception of antiquity or prehistory - the formats that are the closest to the traditional history of art. I sum up the international and Polish studies and comment on the central issues in these approaches.

The second part of the article is entitled: "What the artifacts want?". At the beginning, I discuss the main paradigms in the archeological exhibitions and criticize the so-called aesthetic model. The attention is put to the problems resulting from the aesthetic model - the fetishization of archaeological objects through its reduction to the artistic objects. The question asked in the title of the section, after W. J. T. Mitchell, invites to rethink the relation of archaeology towards art and aesthetics and to cross the dominant ways of thinking about archaeological objects. Cited and discussed projects of Doug Bailey illustrate the alternative approach towards archaeology and art.

The third section reflects on the first case studies touched upon in the area of archaeology and art. The dominant references to Robert Smithson, Richard Long, Mark Dion, and Anselm Kiefer are discussed and commented on. The repetitive texts mark some methodological malaise. Thus, I suggest creating a coherent methodological frame using new masterpieces of art, especially those who are present in archaeological museums more often.

A chance for the inauguration of new research areas occurs when juxtaposed artifacts and works of artists raise affection, interest, supplement each other, comment, and metaphorize the experience of the past. On the other hand, as the transfer of knowledge between art and academy is valid, the exhibitions that mediate in such an area may be an essential step to legitimize these often marginal research at the official universities' curricula.

The fourth part of the article concerns the methodology of studies on the edge of archaeology and art. I discuss there the research strategy presented by Rodney Harrison and John Schofield. Harrison and Schofield propose to treat art as an archaeological record. Another method is an archaeological investigation as a performance, which focuses on archaeology as art. The third approach proposed by Harrison and Schofield is a strategy of art as an interpretation, narrative, and characterization in which the researchers prove how the subjects undertook by archaeologists and artists transfer and complement each other. The authoress also stresses how the history and art critic may benefit from this archaeological marriage by discussing the question of what archaeology may bring to the history and critic of art? I suggest that enriching artistic interpretations with poetics of 
archaeology and elements of archaeological imagery may deepen the semantic potential of works. I preset the actions of the Polish artists: Hubert Czerepok, Joanna Rajkowska, Robert Kuśmirowski, Agnieszka Kalinowska i Agata Ingarden

In the fifth part, I analyze the work of Agnieszka Kurant Archaeology of the foreign (Archeologia obcych) from 2019 about the methodological conditions on the edge of archaeology and art.

In summary, I argue that the current archaeological research on art let us suggest that these studies will develop further and bring archaeologists new inspirations through artistic mediation. Especially the projects presented by Doug Bailey illustrate the most significant benefits for entering the art to archaeological practice. The artistic imagination widens the possibilities of archaeological imagination. It stimulates the researchers to not distinct interpretations, alternative look at artifacts and archaeological sites. The real challenge is not to find analogies between artifacts, archaeological sites, and artistic works, but rather a trial of negotiating between archaeology and art, asking questions about what really art brings to archaeology, interpretation, archaeological sites and artifacts? How does it expand the cognitive possibilities? Does and how it allow for a better understating of the past?

From the above, there are conclusions for the future, especially for two areas: archaeological exhibitions and research on art. It is in museums and art critics where the most radical changes should focus. Taking into account the archaeological interest in contemporary art, we should look for its legitimization in the museums' galleries. Observing the edge of archaeology and art seems to be the most interesting in the reality of museums. The collision of the order of contemporary art and archaeology lets us to revision the current relationship between these two areas - especially a long-lasting tradition of presenting artifacts as works of art. It does not demand to reject but a revision and reinterpretation, which are possible in the times of the growing interest in the past, materiality, fragmentization, ruination, and archaeology among artists. This burdening and oppressive for artifacts relation with the artistic paradigm in the exhibition asks for reworking and confrontation with the contemporary art, to which archeologists refer more often in their studies. The contemporary art slips away from the Kant's aesthetics of beauty and loftiness, it demands engagement from the onlookers, interaction, it moves in the heterogenic aesthetics. The contemporary art and its aesthetics are able to ruin the specific aesthetic paradigm which was imposed on artifacts in the archaeological museums and which link to the classical categories of aesthetics.

The second challenge that results from the development of the horizon of research between archaeology and art is directed into researchers of art. Archaeologists lead themselves towards visual culture, aesthetics, and contemporary art. However, there is no such initiative from the side of art researchers - focusing on archaeological methods, interpretations, main paradigms, and theories. In the times of return to thinks that are stressed by archaeologists cited here, the marriages of archaeology with different humanistic disciplines are not visible. Thus, maybe we should ask again, but this time historians and art critics: what if images are artifacts? 